\title{
PENINGKATAN KETERAMPILAN MENULIS PARAGRAF MELALUI PENERAPAN KEGIATAN MENULIS JURNAL UNTUK PENILAIAN AUTENTIK PADA SISWA KELAS VIII SMP NEGERI 5 TEBING TINGGI
}

\author{
Ellys Tumiar Sitohang
}

Surel: ellystumiar@gmail.com

\begin{abstract}
ABSTRAK
Pembelajaran menulis yang dilakukan belum mendorong terbentuknya kebiasaan menulis pada siswa. Di sisi lain, penilaian pembelajaran menulis yang diterapkan juga belum dapat memberi informasi yang sebenarnya tentang perkembangan keterampilan menulis siswa. Untuk mengatasi hal tersebut, diterapkan kegiatan menulis jurnal pada siswa dan memanfaatkan tulisan dalam jurnal itu untuk bahan penilaian autentik. Dalam penerapannya kegiatan menulis jurnal tersebut dilakukan dalam tiga tahapan. Kegiatan tahapan itu adalah pemahaman konsep dan pemodelan kegiatan menulis jurnal, pelaksanaan dan pembiasaan menulis jurnal. Pendekatan yang digunakan dalam penelitian ini adalah pendekatan kualitatif, sedangkan rancangan penelitian yang digunakan adalah penelitian tindakan kelas. Subjek penelitiannya adalah siswa kelas Kelas VIII SMP Negeri 5 Tebing Tinggi. Hasil penelitian menunjukkan bahwa kegiatan tersebut dapat meningkatkan keterampilan menulis paragraf siswa, baik dari segi kuantitas maupun kualitas paragraf yang dihasilkan. Kegiatan menulis jurnal juga membuat kegiaan menulis menjadi lebih menarik dan bermakna bagi siswa.
\end{abstract}

Kata Kunci : Menulis Jurnal, Hasil, Penilaian Autentik

\section{PENDAHULUAN}

Pembelajaran bahasa Indonesia secara fungsional dan komunikatif adalah pembelajaran yang lebih menekankan siswa untuk belaajar berbahasa, dalam kaitannya dengan fungsi bahasa sebagai alat untuk berkomunikasi. Siswa bukan sekedar belajar tentang pengetahuan bahasa, melainkan belajar menggunakan bahasa untuk keperluan berkomunikasi. Untuk itu, pendekatan pembelajaran yang sesuai adalah pendekatan komunikatif. Pembelajaran bahasa Indonesia dengan pendekatan komunikatif itu diarahkan untuk membentuk kompetensi komunikatif, yakni kompetensi kemampuan untuk menggunakan bahasa Indonesia sebagai alat komunikasi, baik pada aspek pemahaman, aspek penggunaan, maupun aspek apresiasi (Suparno 2001). Hal tersebut diatas berarti, melalui pembelajaran bahasa Indonesia diharapkan siswa memiliki kemampuan untuk menangkap makna dari sebuah pesan atau informasi yang disampaikan serta memiliki kemampuan untuk menalar dan mengemukakan kembali pesan atau informasi yang diterimanya itu. Siswa juga diharapkan memiliki kemampuan untuk mengekpresikan berbagai pikiran, gagasan, pendapat, dan perasaan dengan menggunakan bahasa yang baik. Kompetensi komunikatif itu dapat dicapai melalui 
proses pemahiran yang dilatihkan dan dialami dalam kegiatan pembelajaran.

Salah satu aspek

keterampilan berbahasa yang berkaitan dengan pengungkapan pikiran, gagasan, pendapat, dan perasaan tersebut adalah keterampilan menulis paragraf. Keterampilan menulis paragraf sebagai keterampilan berbagasa yang bersifat produktif-aktif merupakan salah satu kompetensi dasar berbahasa yang harus dimiliki siswa agar terampil berkomunikasi secara tertulis. Siswa akan terampil mengorganisasikan gagasan dengan runtut, menggunakan kosakata yang tepat dan sesuai, memperhatikan ejaan dan tanda baca yang benar, serta menggunakan ragam kalimat yang variatif dalam menulis jika memiliki kompetensi menulis paragraf yang baik.

Berdasarkan pengalaman dan pengamatan di kelas, ditemukan bahwa menulis kerap kali menjadi suatu hal yang kurang diminati dan kurang mendapat respon yang baik dari siswa. Siswa tampak mengalami kesulitan ketika harus menulis. Siswa tidak tahu apa yang harus dilakukan ketika pembelajaran menulis dimulai. Mereka terkadang sulit sekali menemukan kalimat pertama untuk memulai paragraf. Siswa kerap menghadapi sindrom kertas kosong (blank page syndrome) tidak tahu apa yang akan ditulisnya. Mereka takut salah, takut berbeda dengan apa yang diinstruksikan gurunya. Keterampilan menulis di kelas terkadang juga hany diajarkan pada saat pembelajaran menulis saha, pahadal pembelajan keterampilan menulis dapat dipadukan atau diintegrasikan dalam setiap proses pembelajaran di kelas. Pengintegrasian itu dapat bersifat internal dan eksternal. Pengintegrasian internal berati pembelajaran menulis diintegrasikan dalam pembelajaran keterampilan bebahasa yang lain. Menulis dapat pula diintegrasikan secara eksternal dengan mata pelajaran lain diluar mata pelajaran bahasa Indonesia.

Kecenderungan lain yang terjadi adalah pola pembelajaran menulis di kelas yang dikembangkan dengan sangat terstruktur dan mekanis, mulai dari menentukan topik, membuat kerangka, menentukan ide pokok paragraf, kalimat utama, kalimat penjelas, ketepatan penggunaan pungtuasi dan sebagainya. Pola tersebut selalu berulang tiap kali pembelajaran menulis. Pola tersebut tidak salah, tetapi pola itu menjadi kurang bermakna jika diterapkan tanpa variasi strategi dan teknil lain. Akibatnya, waktu pembelajaran pun lebih tersita untuk kegiatan tersebut, sementara kegiatan menulis yang sebenarnya tidak terlaksana atau sekedar menjadi tugas di rumah. Kegiatan menulis seperti ini bagi siswa menjadi suatu kegiatan yang prosedural dan menjadi tidak menarik. Penekanan pada hal yang bersifat mekanis adakalanya membuat kreatifitas menulis tidak berkembang karena hal itu tidak 
mengizinkan gagasan tercurah secara alami. Bahkan, Tompokins (1994:105) menegaskan bahwa terlalu menuntut kesempurnaan hasil tulisan dari siswa justru dapat menghentikan kemauan siswa untuk menulis.

Pembelajaran menulis juga sering membingungkan siswa karena pemilahan-pemilihan yang kaku dalam mengajarkan jenis-jenis tulisan atau jenis-jenis paragraf, seperti narasi, eksposisi, deskripsi, dan argumentasi. Pengategorian yang kaku itu membuat siswa menulis terlalu berhati-hati karena takut salah, tidak sesuai dengan jenis karangan yang dituntut. Padahal, ketakutan untuk berbuat salah tersebut dapat mematikan kreativitas siswa untuk menulis. Selain itu, Halliday (dalam Tompkins \& Hoskisson, 1991:187) menyatakan bahwa pengategorian jenis-jenis karangan tersebut terlihat artifasial ketika kita meminta siswa menggunakannya untuk berbagai tujuan yang berbeda, sebab siswa terkadang mengombinasikan dua atau lebih kategori untuk mengemukakan sebuah gagasan dalam tulisannya.

Menulis merupakan suatu keterampilan dan keterampilan itu hanya akan berkembang jika dilatihkan secara terus menerus atau lebih sering. Memberikan kesempatan lebih banyak bagi siswa untuk berlatih menulis dalam berbagai tujuan merupakan sebuah cara yang dapat diterapkan agar keterampilan menulis meningkat dan berkembang secara cepat.

\section{Fokus Penelitian}

Permasalahan pokok yang menjadi fokus penelitian ini adalah rendahnya keterampilan menulis paragraf siswa Kelas VIII SMP Negeri 5 Tebing Tinggi. dari studi awal yang dilakukan di sekolah itu, ditemukan beberapa indikator yang menunjukkan rendahnya keterampilan menulis siswa di sekolah tersebut. Indikator yang dapat dilihat dari hasil tulisan siswa adalah (1) gagasan utama yang disajikan tidak jelas dan banyak paragraf yang memiliki lebih dari satu gagasan utama, (2) gagasan pengembang yang disajikan tidak padu dan tidak mendukung gagasan utama, (3) banyak paragraf yang hanya terdiri dari atau kalimat, (4) kalimat-kalimat yang digunakan banyak yang memiliki struktur yang tidak tepat, (5) pilihan kata yang digunakan masih terbatas dan kurang tepat, utamanya pada penggunaan konjungsi, dan (6) tanda baca dan ejaan yang digunakan masih banyak kesalahan. Berdasarkan indikatorindikator tersebut hasil tulisan diposisikan pada kualifikasi kurang sampai dengan cukup.

Indikator-indikator rendahnya keterampilan menulis paragraf siswa tersebut didukung pula dengan hasil pengamatan terhadap proses pembelajaran menulis. Hasil pengamatan itu menunjukkan tiga hal yang berhubungan dengan rendahnya keterampilan menulis siswa. 
Pertama, siswa memerlukan waktu yang cukup lama untuk menyelesaikan sebuah paragraf yang baik. Kedua, siswa mengalami kebingungan untuk menentukan topik, gagasan utama, atau kalimat pertama yang akan ditulis. Ketiga, siswa kurang antusias dan tidak menunjukkan respon yang baik ketika mendapat tugas menulis.

Dari hasil analisis dan diskusi disimpulkan dua faktor utama sebagai penyebab rendahnya keterampilan menulis tersebut. Pertama, faktor yang berhubungan dengan strategi pembelajaran keterampilan menulis. Kedua, faktor yang berkaitan dengan proses penilaian pembelajaran keterampilan menulis.

Ada lima indikator faktor penyebab yang berhubngan dengan strategi pembelajaran menulis. Pertama, pembelajaran menulis yang dikembangkan masih dilakukan dengan cara mengutamakan aspek teoritis, mekanis, dan kurang variatif sehingga kurang menarik minat belajar siswa. Kedua siswa belum dibiasakan dan latih untuk menulis secara berkesinambungan. Ketiga, tugas-tugas menulis paragraf atau membuat karangan yang harus dikerjakan siswa sangat formal, dibatasi jenisnya secara berksinambungan. Ketiga, tugastugas menulis paragraf atau membuat karangan yang harus dikerjakan siswa sangat formal, dibatasi jenisnya secara kaku, dan menuntut kesempurnaan hasil sehingga kreativitas siswa untuk mengekspresikan diri melalui tulisan kurang dapat berkembang. Keempat, bimbingan dan penguatan yang diberikan guru terhadap kegiatan menulis yang dilakukan siswa belum optimal. Kelima, pembelajaran menulis yang dilaksanakan cenderung ekslusif, tidak terpadu dengan pembelajaran aspek keterampilan berbahasa lain.

Indikator faktor penyebab yang berkaitan dengan proses penilaian pembelajaran keterampilan menulis ada empat hal. Pertama, penilaian keterampilan menulis hanya dilakukan melalui soal-soal tes sehingpa kurang memperhatikan aspek komunikatif dalam pembeiajarean bahasa. Kedua, penilaian tidak merekam perkembanil-an kemampi:an menulis yang sebenarnva karena tidak dilakukan secara berkelanjutan. Ketiga, peniiaian hanya dilakukan sepihak oleh guru secara tertutup. Keempat, hasil penilaian tidak merefleksi kebutuhan belajar siswa.

Secara umum tujuan penelitian ini adalah mondapatkan kajian tentang upaya meningkatkan keterampilan memalis paragraf siswa kelas Kelas VIII SMP Negeri 5 Tebing Tinggi melalui kegiatan menulis jurnal dan pemanfaatannva untuk penilaian autentik. Tujuan penelitian umum itu diuraikan secara khusus sebagai berikut :

a. Mendapatkan kajian tentang upaya meningkatkan keterampilan menulis paragraf siswa kelas Kelas VIII SMP Negeri 5 Tebing Tinggi melalui 
tindakan pemahaman konsep dan pemodelan?

b. Mendapatkan kajian tentang upaya meningkatkan keterampilan menulis paragraf siswa kelas Kelas VIII SMP Negeri 5 Tebing Tinggi melalui tindakan pelaksanaan dan pembiasaan menulis jurnal dalam pembelajaran?

c. Mendapatkan kajian tentang upaya meningkatkan keterampilan menulis paragraf siswa kelas Kelas VIII SMP Negeri 5 Tebing Tinggi melalui tindakan penilaian autentik dengan memanfaatkan tulisantulisan dalam jurnal siswa?

\section{METODE PENELITIAN}

Pendekatan yang digunakan dalan penelitian ini adalah pendekatan kualitatif Penggunaan pendekatan kualitatif ini didasari pemikiran bahwa penelitian ini berupaya untuk mengungkapkan berbagai gejala yang memberikan makna dan informasi scsuai konteks dan tujuan penelitian melalui pengumpulan data. Pengumpulan data tersebut dilakukan pada latar alamiah dengan peneliti sebagai instrumen utama dalam pengumpulan data.

Sejalan dengan pemfokusan dan latar alaminya yang berwujud aktivitas di dalam kelas, rancangan penelitian tindakan yang diterapkan adalah penelitian tindakan kelas classroom action reserch).

Berdasarkan pendekatan dan rancangan PTK yang akan diterapkan, prosedur dan langkahlangkah penelitian ini mengikuti prinsip-prinsip dasar penelitian tindakan. Oleh karena itu, model rancangan penelitian tindakan kelas yang akan digunakan adalah model spirail-bersiklus sebagaimana dikemukakan Lewin dan dikembangkan oleh kemmis dan Elliot (Elliot, 1991:71). Secara umum model siklus ini meliputi (1) perencanaan, (2) pelaksanaan tindakan, (3) pengamatan, analisis dan refleksi.

Subjek penelitian ini adalah siswa kelas Kelas VIII SMP Negeri 5 Tebing Tinggi yang dilakukan pada September 2016. Seluruh siswa akan dikenai tindakan karena penelitian tindakan kelas adalah penelitian yang mengikuti alur pembelajaran sebenarnva. Pertimbangan pemilihan Kelas VIII sebagai sumber data penelitian karena Kelas VIII merupakan kelas peneliti dalam melaksanakan tugas sehari-hari dan di kelas ini terdapat masalah tersebut. Selain itu, Kelas VIII SMP merupakan kelas tengah, dengan siswa yang telah dapat herpikir secara logis dan abstrak serta telah mempunvai dasar pengetahuan awal tentang keterampilan menulis yang dipelajari di kelas VII. Pengetahuan awal tersebut, misalnya bentuk paragraf, pola-pola kalimat, dan penggunaan ejaan atau pungtuasi.

Data yang ingin diperoleh adalah data tentang proses kegiatan dan data tentang hasil kegiatan menulis jurnal. Data-data itu meliputi (1 ) data awal tentang kemampuan 
kcterampilan menulis paragraf siswa

(2) data pokok tentang upaya peningkatan keterampilan menulis paragraf melalui tindakan pemahaman konsep dan pemodelan kegiatan menulis jurnal. (3) data pokok tentang upaya peningkatan keterampilan menulis paragraf melalui tindakan pelaksanaan dan pembiasaan kegiatan menulis jurna1, (4) data pokok tentang upaya peningkatan keterampilan menulis paragraf melalui tindakan penilaian autentik dengan memanfaatkan tutisan $\neg$ tulisan dalam jurnal siswa, serta (S) data pendukung tentang perkembangan keterampilan menulis siswa setelah tindakan. Untuk memperoleh data penelitian, teknik pengumpulan data yang akan digunakan adalah wawancara, pengamatan, pendokumentasian. dan pemberian tes menulis. Sesuai dengan (karakteristik penelitian kualitatif, dalam penelitian ini peneliti berperan sebagai instrumen utama pengumpulan data. Data-data tersebut berupa transkrip wawancara dan rekaman kegiatan belajar, catatan lapangan dokumentasi hasil tulisan siswa dan hasil tes Menulis.

$$
\text { Analisis data dalam }
$$

penelitian ini akan dilakukan dengan dasar analisis data model alir yang terdiri atas tiga tahapan yaitu (1) mereduksi data, (2) menyajikan data, dan (3) menarik kesimpulan dan memverifikasi. Analisis data tersebut dilakukan selama dan sesudah penelitian, mulai dari tahap perencanaan kegiatan, pelaksanaan.
Hingga refleksi kegnatan.

\section{HASIL PENELITIAN DAN PEMBAHASAN}

Sesuai perencanaan yang telah dibuat tindakan pembelajaran dikembangkan dalam tiga siklus tindakan. Perencanaan yang dibuat, disesuaikan dengan satuan program semester yang telah disusun oleh guru mata pelajaran, sehingga pelaksaaaan penelitian ini tetap berjalan sesuai alur progam pembelajaran mata pelajaran bahasa Indonesia sebagaimana mestinya. kegiatan menulis jurnal dalam penelitian ini menjadi kegiatan suplemen vang terintegrasi dalam pembeiajaran pokok.

Pelaksanaan setiap siklus terdiri atas tiga tindakan pokok. Adapun ketiga tindakan pokok tersebut adalah (1 ) pemahaman dan pemodelan. (2) Pelaksanaan dan pembiasaan kegiatan menulis jurnal, dan (3) pelaksanaan penilaian autentik melalui jurnal. Dalam tiap siklus, tindakan pertama dilaksanakan dengan alokasi waktu dua kali pertemuan jam pelajaran. Tindakan kedua dilakukan terinteigrasi dalam tiap jam pelajaran bahasa Indonesia selama empat kali pertemuan, guru menyediakan waktu sepuluh sampai dengan lima belas menit di menit awal atau di akhir pelajaran untuk menulis. Materi tulisan jurnal disesuaikan dengan konteks materi pembelajaran saat itu. Tindakan ketiga selain dilakukan secara bersinambungan oleh yang, dilakukan pula oleh siswa sekitar dua 
puluh menit pada waktu yang ditentukan. Setiap siklus siswa menulis jurnal sebanvak lima kali.

\begin{tabular}{|c|l|c|c|c|}
\hline No & Indikator & Siklus I & Siklus II & Siklus III \\
\hline & $\begin{array}{l}\text { Siswa } \\
\text { sangat } \\
\text { aktif } \\
\text { menulis } \\
\text { tiap } \\
\text { kegiatan } \\
\text { Siswa } \\
\text { aktif } \\
\text { menulis } \\
\text { tiap } \\
\text { kegiatan }\end{array}$ & $9(3 \%)$ & $4(24 \%)$ & $8(32 \%)$ \\
& $\begin{array}{l}\text { Siswa } \\
\text { kurang } \\
\text { aktif } \\
\text { menulis }\end{array}$ & $6(24 \%)$ & $12(48 \%)$ & $14(66 \%)$ \\
& $\begin{array}{l}\text { Siswa } \\
\text { Pasif }\end{array}$ & $3(16 \%)$ & $3(12 \%)$ \\
& $\begin{array}{l}\text { Jumlah } \\
(100 \%)\end{array}$ & $(100 \%)$ & - \\
\hline
\end{tabular}

Dari data penelitian terlihat terjadi peningkatan aktivitas siswa selama pelaksanaan tindakan. Pada siklus I masih banyak siswa yang belum atau kurang aktif untuk menilis. Namun, pada siklus II dan III jumlah siswa yang aktif dan sangat aktif menulis terus meningkat. Bahkan, pada akhir siklus III tidak terlihat siswa yang pasif atau tidak menulis jurnalnya.

Peningkatan tersebut dapat tercapai karena bimbingan Guru yang diberikan secara dinamis dan tidak prosedural. Sekalipun menulis jurnal bersifat menulis informai. tetapi bimbingan tetap diberikan sehingga dapat menggali ide-ide kreatif siswa dalam menentukan topik dan mengemukakan gagasan. Guru jug berupaya mengaitkan kegiatan menulis jurnal tersehut dengan konteks kehidupan atau materi pembelaiaran sehingga gagasan yang ditulis dapat merefleksikan perkembangan hasil belajar dan perkembangan pribadi siswa. Selain itu, respon tertulis vang, diberikan yang ternyata mampu meningkatkan motivasi untuk menulis. Motivasi itu tumbuh karena siswa merasa guru menghargai dan peduli dengan apa vang ditulisnya.

Pada awal pembiasaan menulis jurnal, siswa banyak membutuhkan waktu untuk menghasilkan sebuah paragraf. tetapi setelah beberapa kali menulis siswa menjadi semakin terampil. Bahkan dalam perkembangannya siswa mau membuat buram tulisannya di rumah, meskipun guru tidak menugaskan ha1 itu. Dampaknya, pemberian waktu sepuluh sampai lima beias menit yang awalnya terkesan mengurangi waktu pembelajaran pokok dapat dimanfaatkan secara efektif, menjadi berharga, dan lebih bermakna dalam upaya melatih keterampilan menulis siswa.

Dampak positif lain yang ditemukan dari pembiasaan menulis jurnal adalah tumbuhnya kemauan dan keterbukaan siswa untuk mengkomunikasikan atau mengekspresikan secara tertulis berbagai masalah atau peristiwa yang dialami. Selain itu, kehbngungan siswa menentukan topik atau kalimat pertama saat mulai menulis dapat teratasi melalui pembiasaan menulis jurnal.

Rangkaian pelaksanaan tindakan menulis jurnal adalah kegiatan penilaian autentik dengan memanfaatkan tulisan-tulisan jurnal 
siswa. Penilaian autentik ini meiiputi kegiatan penilaian diri sendiri, penilaian sejawat antar siswa, dan penilaian oieh guru. Kegiatan penilaian autentik ini menjembatani kesenjangan antara menulis jurnal sebagai kegiatan menulis informai dengan pembelajaran keterampilan menulis paragraf secara formal di sekolah.

Ada empat indikator peningkatan keterarnpilan menulis paragraf siswa yang tampak sebagai dampak dari tindakan penilaian autentik yang dilakukan oleh siswa. Keempat indikator itu adalah (1) meningkatnya kemampuan mengidentifikasi berbagai kesalahan penggunaan ejaan dan tanda baca yang terdapat daiam sebuah tulisan.

(2) meningkatnya kemampuan mengidentifikasi kalimat yang sumbang dalam paragraf (3) meningkatnya kemampuan mengoreksi dan memperbaiki struktur kalimat yang kurang tepat, dan (4) meningkatnya kemampuan untuk mengidentifikasi dan memperbaiki pilihan kata yang kurang tepat.

Penilaian autentik ini juga mendorong siswa untuk mengkonstruksi sendiri pengetahuannya tentang kaidahkaidah teknik penulisan yang benar karena siswa belajar dari mencermati, mengidentifikasi kesalahan-kesalahan dalam tulisan, dan memperbaiki kesalahankesalahan tersehut. Kemampuan mengidentifikasi berbagai kesalahan tersebut mendorong siswa untuk menulis paragrah secara lebih cermat sehingga tidak mengulangi kesalahan serupa saat menulis paragraf dalam jurnal berikutnya. Di sisi lain, semangat kerja sama dan percaya diri siswa semakin terbangun melalui kegiatan ini. Siswa belajar untuk bersikap jujur dan berani menilai serta menghargai hasil pekerjaannya sendiri maupun pekerjaan temannya. Penilaian autentik yang dilakukan guru juga berpengaruh terhadap peningkatan keterarnpilan menulis paragraf siswa karena Guru tidak sekedar memberikan penilaian langsung pada hasil tulisan sisw.a, tetapi mengumpuikan informasi berdasarkan aktivitas siswa saat menulis dan mereatat kesalahanKesalahan yang cenderung dan kerap dilakukan siswa dalam tulisannya. Informasi ini berguna untuk perencanaan dan penyesuaian kebutuhan belajar siswa. Guru juga melakukan penilaian dengan mendokumentasikan perkembangan kualitas tulisan siswa tiap pertemuan secara berkesinambungan karena hasil dokumentasi itu memberikan gambaran tentang peningkatan kemampuan menuiis paragraf siswa yang sebenarnya.

\section{SIMPULAN}

Salah satu permasalahan yang dihadapi dalam pembelajaran bahasa Indonesia di sekolah adalah rendahnva keterampilan menuiis paragraf siswa. Hal itu terlihat dari rendahnva kualitas paragraf yang dihasilkan siswa. Siswa juga kurang antusias dan mengalami kesulitan 
ketika mendapat tugas untuk menulis. Hal tersebut diindikasikan karena pembelajaran menulis yang dilakukan belum mendorong dan membentuk kebiasaaan siswa untak menulis. Pembelajaran menulis yang disajikan belum memberi kesempatan banyak pada siswa untuk menulis. Di sisi lain penilaian keterampilan menulis juga belum dilakukan secara komprehensif dan berkesinambungan. Untuk mengatasi permasalahan tersebut; salah satu alternatif tindakan yang dapat diterapkan adalah penerapan kegiatan menulis jurnal dan memanfaatkan hasil tulisan siswa dalam jurnal untuk penilaian autentik.

Penerapan kegiatan menuiis jurnai ini dapat memberikan kesempatan lebih banyak kepada siswa untuk mengekspresikan gagasan secara tertulis. Dengan terbiasa dan lebih sering menulis, kualitas paragraf-paragraf yang dihasilkan dapat semakin baik. Dengan, terbiasa menulis kreativitas siswa dalam menulis pun meningkat. Siswa semakin mudah dan terbiasa menemukan berbagai bahan atau gagasan yang dapat ditulisnya.

Penerapan autentik oleh siswa maupun guru dengan memanfaatkan hasil tulisan jurnal siswa juga dapat memberi pengaruh yang besar terhadap peningkatan keterampilan menulis paragraf siswa. Dengan menilai hasil tulisannya sendiri maupun hasil tulisan teman; siswa dapat mengkonstruksi dan menemukan sendiri pengetahuannya
Siswa belajar dari berbagai kesalahan untuk menulis lebih baik. Di Sisi lain guru juga dapat memanfaatkan hasil autentik tulisan dalam jurnal siswa sebagai sumber informasi untuk melibat perkembangan belajar siswa.

Dalam pelaksanaannya. kegiatan menulis jurnal dan penilaian autentik tersebut dilakukan secara terpadu dan terintegrasi dengan kegiatan pokok pembelajaran bahasa lndonesia.

\section{DAFTAR RUJUKAN}

Depdikbud. 1999. Penelitian Tindakan (Action Research).

Bahan Pelatihan. Jakarta: Dikdasmen Depdikbud.

Depdiknas. 2003. Kurikulum 2004. Standar Kompetensi Mata Pelajaran Bahasa dan Sastra Indonesia SMA dan MA (Draf Final). Jakarta: Depdiknas.

Capacchione. L. 1989. The Creative Journal For Children: A Guide for Parents, Teacher, and Counselors. Boston: Shambala.

Eanes, R. 1997. Content Area Literacy: Teaching Today's and Tomorrow. New York: Delmar Publisher.

Elliot, J. 1991. AN. Action Reseach for Educational Change. Buckingham: Open University Press.

O’Malley, J.M. \& Piece, L.V. 1996. Authentic Assessment for Ennglish Language Learners: Practical Approaches For Teachers. Virginia: AddisonWesley. 
Ellys Tumiar Sihotang : Peningkatan Keterampilan ...

Puhl, C. 1997. Develop, Not Judge: Continuous Assesment in the ESL Classroom. English Teaching Forum, April 1997, pp 2-9.

Saukah, A. 1999. Prinsip Dasar Penilaian Pendidikan Bahasa. Bahasa dan Seni. Tahun 27, Nomor 1, Pebruari 1999, Hal; 19- 33.

Saukah, Ali. 2001. The Teaching Writing and Grammar. Bahasa dan Seni. Tahun 28, Nomor 2, Agustus 2000, Hal. 191-199.

Suparno, 2001. Pembelajaran Bahasa Indonesia dengan Pendekatan Kontekstual. Makalah disajikan pada Simposium di Wisma Jaya. Bogor: Direktorat SLTP, Dirjen Dikdasmen. November, 2001.

Suyanto, K.E. 2002. Authentic Assesment (Penilaian Otentik) dalam Pembelajaran Bahasa. Materi Pelatihan Calon Pelatih Pembelajaran Kontekstual Mata Pelajaran Bahasa Inggris Guru SLT di Malang. Direktorat SLTP, Depdiknas. 2002. 